\title{
Nekrolog: Henning Eichberg
}

\author{
JØRN HANSEN, BJARNE IBSEN OG JØRGEN POVLSEN
}

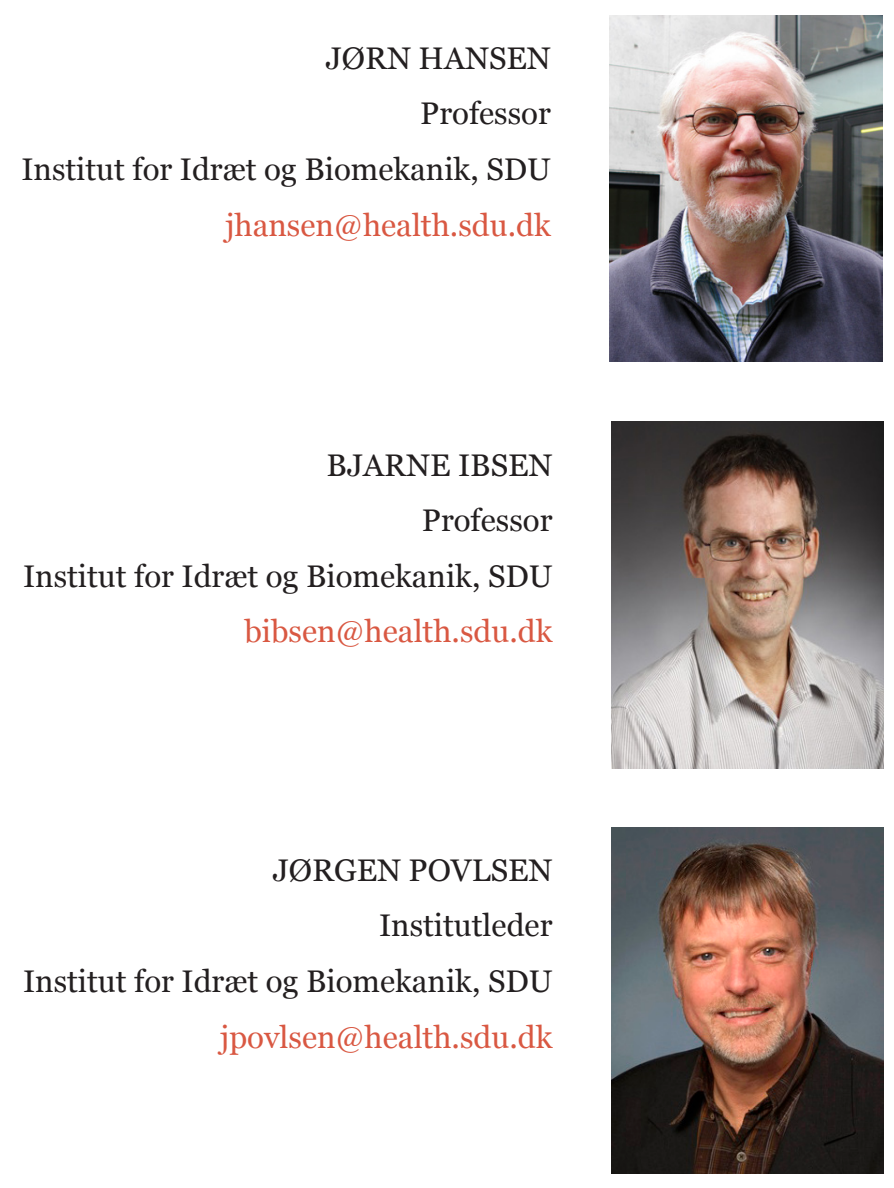

Professor emeritus, Dr. Phil. Habil. Henning Eichberg døde den 22. april 2017 i Odense. Fra 2004 til 2015 var Henning Eichberg ansat ved Institut for Idræt og Biomekanik, SDU, tilknyttet Center for Forskning i Idræt, Sundhed og Civilsamfund og forskningsenheden Bevægelse, Kultur og Samfund. Fra 2015 fastholdt han som professor emeritus en tæt tilknytning til sin gamle arbejdsplads og var indtil sin død stadig en særdeles produktiv forsker. 
Henning Eichberg blev født i 1942 i Schlesien. I 1950 flyttede familien fra DDR til Hamborg, hvor han tilbragte sin ungdom med politisk ungdomsarbejde og studerede historie og litteratur. Hans første forskningsprojekt om teknologi-historie og militær kultur førte til erhvervelsen af Ph.d.-graden i historie i 1970 ved Ruhr Universitet i Bochum. I 1971 blev Eichberg ansat ved Institut for Sociologi, Stuttgart Universitet, hvor han arbejdede med historisk adfærdsforskning. Fra 197475 arbejde han med socialantropologiske studier i West Sumatra. Hans doktorafhandling (habilitation) i Stuttgart bestod af to bøger, et historisk studie om den moderne sports oprindelse og dans i det 18. og 19. århundrede og et antropologisk studie om rural udvikling og social forandring i West Sumatra. Frem til 1982 var Eichberg tilknyttet Stuttgart Universitet.

I 1982 førte arbejdet med den moderne sports oprindelse Henning Eichberg til Danmark. Kulturministeriet havde reserveret midler til et gæsteprofessorat, der skulle medvirke til at opbygge den humanistisk samfundsvidenskabelige idrætsforskning i Danmark, og fra 1982 til 1984 var Eichberg gæsteprofessor ved Institut for Idræt, Odense Universitet, og fra 1984 til 1987 ved Kultursociologi Københavns Universitet. Fra 1987 til 2004 arbejde han som seniorforsker ved Idrætsforsk, Gerlev Idrætshøjskole, hvor han i mange år boede og levede sig ind i den danske højskoletradition. En kort periode 1989-1991 var han ligeledes seniorstipendiat ved Danmarks Højskole for Legemsøvelser, København. I 2004 kom Eichberg atter tilbage til Odense, nu Syddansk Universitet og Institut for Idræt og Biomekanik.

Få har som Henning Eichberg sat så afgørende aftryk på den kulturelle og samfundsvidenskabelige idrætsforskning internationalt og i Danmark. Henning Eichberg har forfattet, været medforfatter til eller redigeret mere end 50 bøger og har publiceret kapitler i mere end 240 bøger samt utallige artikler i tidsskrifter på 17 forskellige sprog. Selv har Eichberg angivet, at han fandt sit eget kropskulturelle og sportskritiske ståsted under inspiration fra Michel Foucault, Norbert Elias samt August Nitschke (Eichbergs "doktorvater", der arbejdede med historisk adfærdsforskning).

Tematisk kan Henning Eichbergs forskning opdeles i følgende hovedområder:

- Kropskulturforskning, hvor han har inspireret flere yngre forskere med sin konfigurationsanalyse omhandlende rum, tid, energi, interpersonelle relationer og produktion i menneskelige bevægelser.

- Sporten i moderniteten, hvor betoningen af den moderne sports forskellighed fra den før-moderne sport tydeliggøres i form af et konfigurationsskifte.

- Sportskritikken og sporten som et område for kulturelle kampe, hvor det drejer sig om en kritik af den olympiske sport og en søgen efter alternative folkelige lege.

- Traditionelle lege, friluftsliv og grønne bølger. En forskning han videreførte i 
sine seneste publikationer, der handlede om at udarbejde en filosofi om leg.

- National identitet, hvor Eichberg med sin teori om folk, kulturelle minoriteter og etnopluralisme frem for etnocentrisme skabte kolossal debat i de tyske intellektuelle miljøer, fordi hans arbejde med disse problemstillinger startede, mens han var forankret i den tyske højrefløj. Senere, da Eichberg fandt et ståsted i Socialistisk Folkeparti i Danmark, fortsatte han diskussionen om det nationale spørgsmål, og "hvem er vi”. Ud over disse hovedområder fandt Eichberg også mere utraditionelle forskningsområder interessante, fx "nisseforskning" eller forskning i labyrinternes historie.

Eichbergs forskning omfattede således både meget akademiske spørgsmål og problemstillinger ud fra en erkendelsesmæssig interesse samt forskning, der forholdt sig til aktuelle kulturelle og politiske problemstillinger. På den måde fik han stor betydning for idræts- og kulturkritikken, men mødte af samme grund også modstand fra de, der ikke ønskede en sådan kritik.

Grundlaget for forskningen og kritikken var Hennings kolossale viden og belæsthed; han var i klassisk forstand et dannet menneske. Næsten lige gyldigt, hvilket emne, man kom til at diskutere med Henning, så havde han på et tidspunkt læst om dette og var i stand til at reaktualisere problemstillingerne. Henning elskede faglige debatter, han kunne være skarp i sin kritik af noget, han mente var fejlagtigt, eller han var uenig i, men han var aldrig uvenlig eller nedladende i sin kritik. Heller ikke, når han selv blev angrebet ud fra et mere eller mindre lødigt ståsted, blev han nedladende. Hans venlige og generøse tilgang til diskussioner var en del af hans personlighed.

På faglige seminarer - Henning brød sig ikke om store kongresser med manglende plads til faglige diskussioner - hvor de faglige diskussioner ofte fik ekstra bid efter nogle glas vin, deltog Henning også veloplagt, selv om han var afholdsmand. Som han sagde, ”jeg behøver ikke alkoholen, jeg bliver høj af at diskutere”.

Henning Eichberg efterlader sig sin hustru, professor Kaya Roessler med hvem han har to døtre samt tre sønner fra et tidligere forhold. Vores tanker går til dem.

Med Hennings død, har vi mistet en original forsker, en vellidt kollega og ven og et storsindet menneske.

Æret være hans minde.

Jørn Hansen

Professor
Bjarne Ibsen

Professor
Jørgen Povlsen

Institutleder 